\title{
Characteristics and current situation of urban forests in Kharkiv region
}

\author{
S. Musienko ${ }^{1} \bowtie$, O. Lyalin ${ }^{1}$, L. Tkach 1 , V. Babenko ${ }^{1}$, M. Sulkowska ${ }^{2}$ \\ ${ }^{1}$ O.M. Beketov National University of Urban Economy in Kharkiv, Faculty of Architecture, Design and Fine Arts, \\ Department of Forestry and Horticulture, Marshal Bazhanov Street 17, 61002 Kharkiv, Ukraine, \\ phone: +38 05770731 09, fax: +38 05770615 54, e-mail: musienkosergij_les@ukr.net \\ ${ }^{2}$ Forest Research Institute, Department of Sylviculture and Genetics of Forest Trees, Braci Leśnej 3, Sękocin Stary, \\ 05-090 Raszyn, Poland
}

\section{Abstract}

The main aim of our study was to examine the current state and to analyse the prospects of the development of urban forests in the city of Kharkiv.

Modern methods of assessment and forest resources ranking were used in the evaluation process. The data from the last basic forest inventory and the electronic database of the 'Ukrderzhlisproekt' Production Association are used.

Conducted investigation enables to assess the state of the urban forests in Kharkiv, to show the division of forest resources by the land category, to list the species composition according to the forests stakeholders as well as to compare the existing and optimal division subject to the age group and to calculate the average forest valuation indicators.

Our results indicated that the urban forests have different indicators in the context of permanent users. The existing division of the forest stands by the age group and average forest valuation indicators do not satisfy the optimal ones. Thereby, the vital problem in solving the issue of the conducting forestry in the urban forests transferred to the scientific base for the provision of their optimal growth, development and carrying out of their functions in full exists to date.

\section{KeY WORDS}

ecology, forest, recreation, town, Ukraine

\section{INTRODUCTION}

Before the beginning of the 21st century, a range of problems caused by the environmental deterioration in large cities had been fully formed; this is certainly true for the city of Kharkiv. The city is located in the north-east of Ukraine (Slobozhanschina). It is the ad- ministrative centre of the Kharkiv region and a large scientific, cultural, industrial and transport centre of Ukraine.

First of all, rapid development of urbanisation, as historical process, has increased the role of cities in society associated with industrialisation and active spreading of urban lifestyle. 
Saved up to the present, forest areas surrounding the city of Kharkiv became one of the most important components of the urban landscape. They purify the polluted air, enrich it with oxygen, create a favourable climatic environment and are a favourite recreational place (Basos 2008).

Forest is an important part of the environment. As an ecological system, it performs different functions and, at the same time, is an essential natural resource. It is a complex, self-supporting natural formation in which unparalleled bonds combine many elements, such as trees, shrubs and herbaceous vegetation, fauna, mycoflora and planting media with its flora and fauna, and with the processes that occur there (Andresen 1978).

Forests have a global significance as a resource and nature protection factor; they are crucial for economic development and maintaining all life forms. They form a natural environment, and their functions are numerous and multifaceted. Environmental conditions are defined by water-conservation, soil-protective, climateregulating and sanitary properties of a forest.

First of all, a forest is a gigantic natural factory of oxygen $\left(\mathrm{O}_{2}\right)$, which gets into the air during the process of photosynthesis, through absorption of carbon dioxide $\left(\mathrm{CO}_{2}\right)$. Together with the oxygen, trees produce many substances that have antibacterial properties, such as phytoncides. Under the influence of phytoncides, forest air, for instance, in pine plantations is almost sterile (Kuchelmeister 1997).

Forests play a big part as filters; they improve the air quality by controlling pollutions produced by industry and transport. A special place in the green planting of urban areas is occupied by urban forests. They are the most heavily visited by people and protect the settlements from hot winds in summer and cold ones in winter and are an air reservoir for the population $(\mathrm{Ku}-$ rakin 2006).

Forest management based on scientific principles contributes to the optimal solution of problems regarding sound protection, rational use and effective reproduction of forest resources.

Forests can be under state, communal or private ownership.

Subjects of ownership of the forests are the state, local communities, citizens and legal persons (Forest Code of Ukraine 1994).
The urban forest is the forest area or forest, located within the settlement.

Forest-park is forest area with elements of park amenities for a public recreation (Rules of maintenance of community landscape in Ukraine 2006; 'Forests of Ukraine' State Target Program 2009).

These days, the role of forests in biosphere stability maintaining is universally recognised. Only forests, amongst other natural systems, have a maximum capacity to stabilise environment; they are regarded as one of the important factors of life support for the society and as an important link in the system of sustainable development (Stolberg 2000).

Forests take on great importance in urban planning. They play a significant role in the environment conditioning because they can improve the hygienic and sanitary conditions for the population. Plantings have a positive impact on wind strength, heat and air regimes that have a significant recreational value for a human being and also are a place of public recreation and location of various cultural and educational events (Stolberg 2000; Konijnendijk et al. 2006; Shackleton 2012; Tasoulas et al. 2013).

There are more than 36,000 bacteria in $1 \mathrm{~m}^{3}$ of the air in a city, whereas in a forest, their number is 40-70 times less because of phytoncides (Kuchelmeister 1997; Kurakin 2006; Pautasso 2009).

Under intensive urbanisation, expansion of existing cities, development of all types of transport and activation of urban life, a number of questions arise concerning forest management in urban areas (Andresen 1978; Kurakin 2006; Basos 2008).

Now there is a problem of sustainable improvement in environmental and sanitary-epidemiological safety of living of urban dwellers under deterioration of ecological condition of large cities. To solve it, the further study of urban forests development at the present stage of urban areas progressing is required.

Forest management based on scientific principles contributes to the optimal solution of problems regarding sound protection, rational use and effective reproduction of forest resources.

The aim of the study is to develop algorithm to increase productivity, sustainability and water-conservation, soil-protective, climate-regulating and sanitary properties of urban forests. 


\section{MATERIAL AND MEthOdS}

The current state of urban forests was analysed and studied following the data of the last basic forest surveying and the content of subcompartment database of the 'Ukrderzhlisproekt' Production Association. Calculations were performed using modern information technologies and computer engineering. The forest stands areas were distributed by species, land use categories, diameter, height, density, forest site capacity, age classes and other menstruation indicators in the context of users.

The analysis of urban forests was carried out based on the electronic database of the 'Ukrderzhlisproekt' Production Association. The forest surveying database was converted from .vff to .mdb format for MS Access software using the program developed in the Laboratory of New Information Technologies of Ukrainian Research Institute of Forestry and Forest Melioration.

The query was generated in the database designed in the ACCESS format using 4 layouts: forest growth conditions (GROWCOND), subcompartment (PLOT), layer (LAYER) and tree stand (STAND).

Region (REGN), forest economy (FADM), forestry (FORY), compartment (KVRT), protection category (PROT), subcompartment (PLOT) and subplot (SPLT) fields were common for the layouts.

In addition, the query included predominant species (KAPL), site class (KAB), forest type (KATL), forest site type (KATU), age group (KAGV) and origin (KAPH1) fields from the forest growth conditions (GROWCOND) layout.

From the subcompartment (PLOT) layout, the land category (KAKZ), year of the last inventory (KAVQ) and area (SQUARE) fields were included in the query.

From the layer (LAYER) layout, the layer (LAYR), stand density (KAP_), stock per hectare (KAMG) and layer stock (KAMJ) fields were included in the query.

The following fields were added to the query from the stand (STAND) layout: the species number in a subcompartment (nPage), species (KASP), origin (KAPH2), age (KAA_), diameter (KAD_), composition (KASS), height (KAH_), the percentage of merchantable wood (KAND), total cross-sectional area (KAGS) and subcompartment stock (KAMQ).

Taking into account the fact that the urban forests were investigated, the query was narrowed to the corresponding protection categories. The generated query was exported to MS EXCEL for further analysis (Vedmid 2006).

To achieve the aim, it was provided

1. To study the ownership and business entities,

2. To make a schematic map of Kharkiv urban forests,

3. To determine a species range of urban forests,

4. To determine forest inventory indices of urban forests.

\section{Results}

The total area of forest fund of the Kharkiv region is 287,000 ha, of which 284,000 ha is covered with forest vegetation. The total area of urban forests is about 51,000 ha.

The timber volume is about 69 million $\mathrm{m}^{3}$. The bulk of forest stands are middle-aged stands, they constitute $64 \%$; young stands account for $10 \%$, the stands of approaching maturity constitute $13 \%$, mature and overmature stands are $13 \%$. The average age of stands is 70 years.

The most commonly species are silver birch (Betula pendula Roth.), black locust (Robinia pseudoacacia L.), common alder (Alnus glutinosa (L.) Gaerth.), English oak (Quercus robur L.), Norway maple (Acer platanoides L.), field maple (Acer campestre L.), small-leafed lime (Tilia cordata Mill.), aspen (Populus tremula L.), Scots pine (Pinus sylvestris L.), white poplar (Populus alba L.) and common ash (Fraxinus excelsior L.). The predominant species are English oak and Scots pine, representing $54 \%$ and $32 \%$ of the forest covered area, respectively.

Forests in the region belong to different institutions. The main forest area $(319,500$ ha, or $76.1 \%)$ is under State Forest Resources Agency of Ukraine, which implements forest management and forest law compliance.

The total area of urban forests in Kharkiv region is 4,670.7 ha, of which $4,253.1$ ha are covered with forest vegetation. The timber volume is estimated to be 1 million $\mathrm{m}^{3}$. The bulk of forest stands are middle-aged ones accounted for $85 \%$; young stands constitute $6 \%$; the stands of approaching maturity are $5 \%$; mature and overmature plantations occupy $4 \%$. The average age of plantations is 69 years.

The most common species are silver birch (B. pendula Roth.), black locust ( $R$. pseudoacacia L.), white 
willow ( $S$. alba L.), common alder (A. glutinosa (L.) Gaerth.), English oak (Q. robur L.), Norway maple (A. platanoides L.), ash-leafed maple (Acer negun- do L.), small-leafed lime (T. cordata Mill.), aspen $(P$. tremula L.), Scots pine (P. sylvestris L.), white poplar (P. alba L.), black poplar (Populus nigra L.),

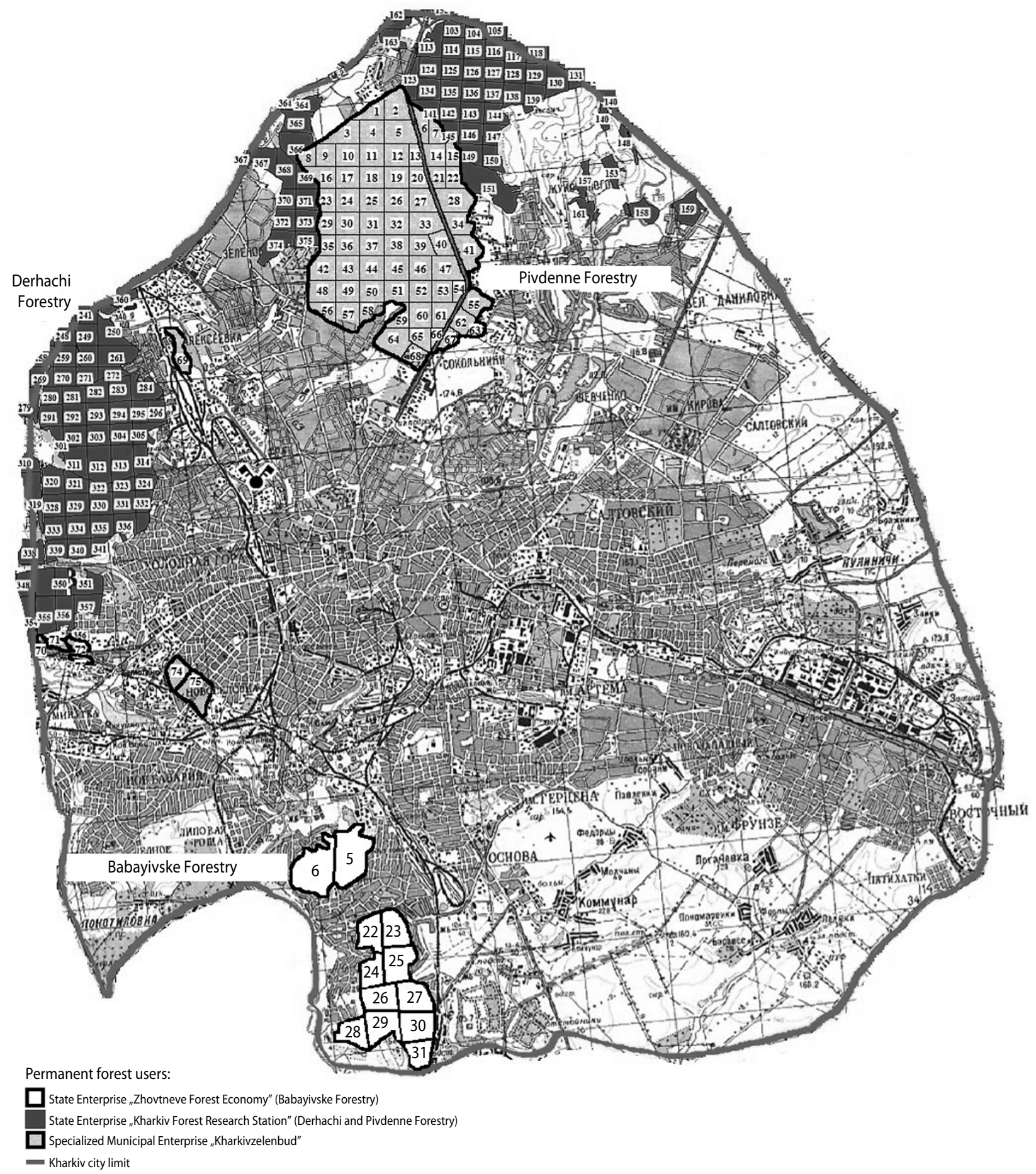

Figure 1. The schematic map of Kharkiv urban forests 
Table 1. Distribution of Kharkiv urban forests by users and ownership

\begin{tabular}{|c|l|l|c|c|c|}
\hline $\begin{array}{c}\text { Item } \\
\text { No }\end{array}$ & \multicolumn{1}{|c|}{ User } & \multicolumn{1}{|c|}{ Departmental subordination } & Ownership & $\begin{array}{c}\text { Area of the } \\
\text { forest fund } \\
\text { (ha/\%) }\end{array}$ & $\begin{array}{c}\text { Area of lands } \\
\text { covered with forest } \\
\text { vegetation (ha/\%) }\end{array}$ \\
\hline 1 & SE 'Zhovtneve FE' & $\begin{array}{l}\text { State Forest Resources Agency of Ukraine } \\
\text { Kharkiv Regional Department of Forestry } \\
\text { and Hunting }\end{array}$ & State & $\frac{512}{13.6}$ & $\frac{506.5}{15.1}$ \\
\hline 2 & $\begin{array}{l}\text { SE 'Kharkiv Forest } \\
\text { Research Station' }\end{array}$ & $\begin{array}{l}\text { State Forest Resources Agency of Ukraine } \\
\text { Ukrainian Research Institute of Forestry } \\
\text { and Forest Melioration named after G.M. } \\
\text { Vysotsky }\end{array}$ & State & $\frac{1,161.8}{30.8}$ & $\frac{1,161.8}{34.5}$ \\
\hline 3 & SME 'Kharkivzelenbud' & Kharkiv City Council & Communal & $\frac{2,092.0}{55.6}$ & $\frac{1,696.0}{50.4}$ \\
\hline
\end{tabular}

Canadian poplar (Populus deltoides Marsch.) and common ash ( $F$. excelsior L.). Amongst them, both English oak and Scots pine are predominant species, which are $61 \%$ and $27 \%$, respectively, of the forest covered area.

The area of Kharkiv urban forests is $3,765.8$ ha, of which 3,364.3 ha are covered with forest vegetation (Fig. 1).

There are two forms of ownership for Kharkiv urban forests - state-owned forests $(44.4 \%)$ and forests of communal ownership (55.6\%) (Tab. 1). Forests under the state ownership are assigned to use in perpetuity to two regular users, State Enterprise (SE) 'Zhovtneve Forest Economy' (Ukraine) (13.6\%) and State Enterprise (SE) 'Kharkiv Forest Research Station' (Ukraine) (30.8\%). They are subordinated to State Forest Resources Agency of Ukraine.

Forests under communal property are in use of Kharkiv City Council, and a specialised municipal enterprise (SME) 'Kharkivzelenbud' (Ukraine) (55.6\%) has the responsibility to operate there.

Table 1 shows the total area 3364.3 ha covered by forest, of which $15.1 \%$ belongs to lands of SE 'Zhovtneve FE', 34.5\% to SE 'Kharkiv Forest Research Station' and $50.4 \%$ to SME 'Kharkivzelenbud'.

The distribution of the total area of urban forest stands by the categories of forest plots is given in Table 2 .

Distribution of plantations by natural and artificial ones is as follows: for SE 'Zhovtneve FE', natural stands constitute $10 \%$, artificial ones account for $90 \%$; for SE 'Kharkiv Forest Research Station', natural stands are $72 \%$, artificial ones are $28 \%$; for SME 'Kharkivzelenbud', the proportion is $88 \%$ for natural stands and $12 \%$ for artificial plantations.

On an average, in Kharkiv urban forests, the bulk of forest stands are middle-aged stands, they constitute $91 \% ; 5 \%$ are the stands of approaching maturity; young plantations account for 3\%; mature and overmature stands are $1 \%$ (Fig. 2).

Table 2. The distribution of the total area of forest fund by forest plot categories (ha)

\begin{tabular}{|c|c|c|c|c|}
\hline Land category & 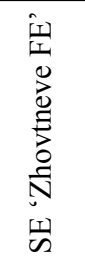 & 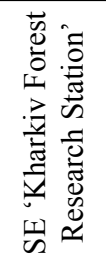 & 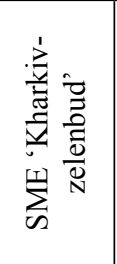 & Total \\
\hline $\begin{array}{l}\text { 1. Area of forest fund } \\
\text { lands }\end{array}$ & 512 & $1,161.8$ & $2,092.0$ & $3,765.8$ \\
\hline 2. Forest plots - total & 512 & $1,161.8$ & $1,756.6$ & $3,430.4$ \\
\hline $\begin{array}{l}\text { 2.1. Forest plots } \\
\text { covered with forest } \\
\text { vegetation - total }\end{array}$ & 506.5 & $1,161.8$ & $1,696.0$ & $3,364.3$ \\
\hline $\begin{array}{l}\text { including forest } \\
\text { plantations }\end{array}$ & 462.5 & 326.7 & 240.5 & $1,029.7$ \\
\hline $\begin{array}{l}\text { 2.2. Forest plots not } \\
\text { covered with forest } \\
\text { vegetation }\end{array}$ & 5.5 & - & 60.6 & 66.1 \\
\hline $\begin{array}{l}\text { 3. Non-forest lands - } \\
\text { total }\end{array}$ & $*$ & $*$ & 335.4 & 335.4 \\
\hline
\end{tabular}

* Data are not available. 


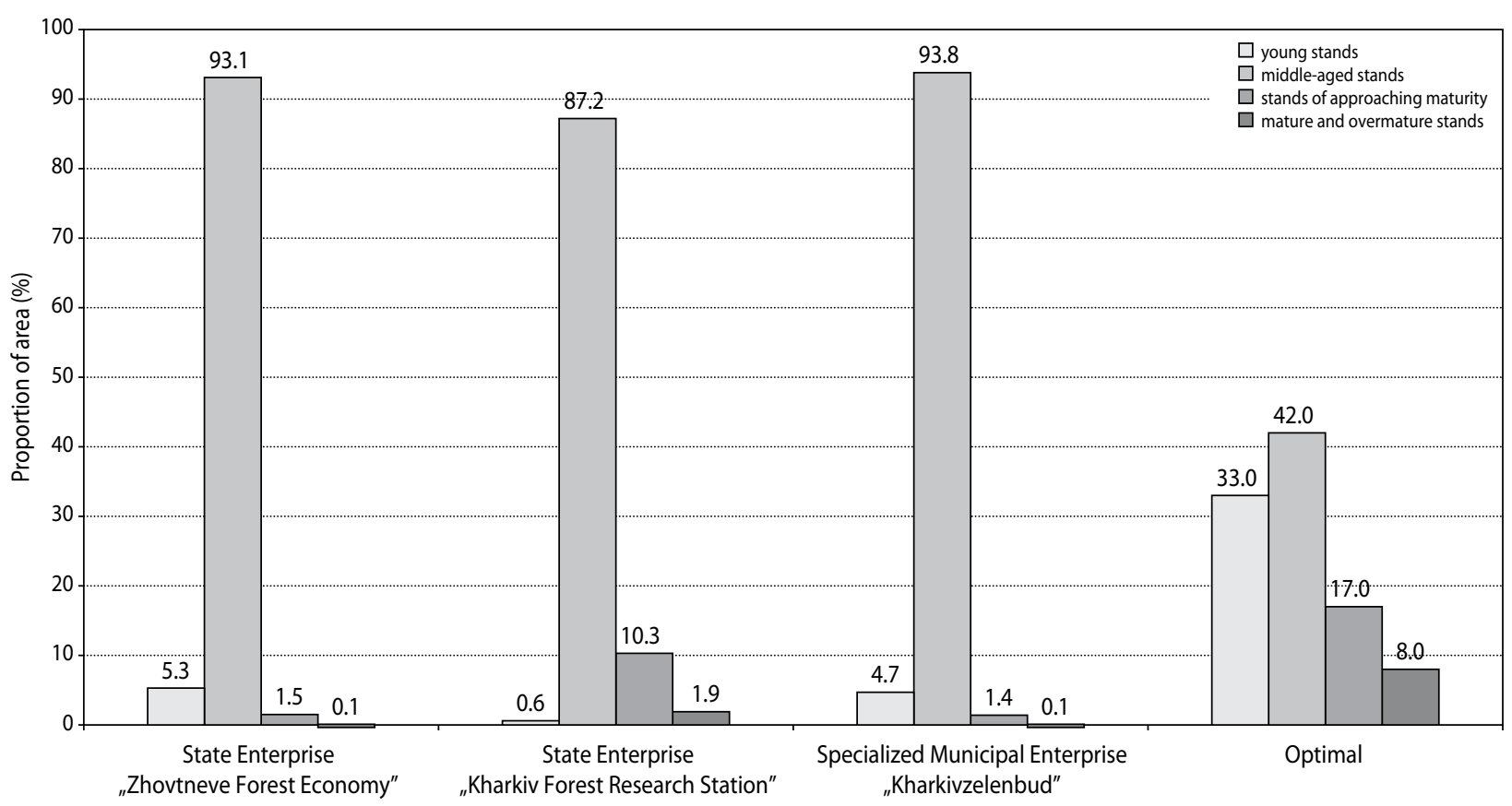

Figure 2. Existing and optimal stands distribution by age groups

From Figure 2, it is clearly defined that the current distribution by age groups in terms of all users is significantly different from the optimal, and, therefore, further study is required (Shvydenko et al. 1987; Instructions of inventory of forest fund of Ukraine 2014).

The common species are silver birch (B. pendula Roth.), black locust ( $R$. pseudoacacia L.), white willow (S. alba L.), common alder (A. glutinosa (L.) Gaerth.), English oak ( $Q$. robur L.), Norway maple (A. platanoides L.), ash-leafed maple (A. negundo L.), smallleafed lime ( $T$. cordata Mill.), aspen (P. tremula L.), Scots pine ( $P$. sylvestris L.), white poplar ( $P$. alba L.), black poplar ( $P$. nigra L.), Canadian poplar ( $P$. deltoides Marsch.) and common ash (F. excelsior L.). Both English oak and Scots pine predominate amongst all common species, covering $61 \%$ and $27 \%$ of the forest covered area, respectively (Tab. 3).

The distribution of average forest inventory indicators of stands is presented in Table 4.

As Table 4 shows, forest stands of SE 'Zhovtneve FE' are characterised by the best productivity, which are evidenced by the average inventory indicators.

\section{Discussion}

The urban forests of Ukraine account for $0.5 \%$ of the total area of Ukrainian forests (Forests of Ukraine 2017). In the Kharkiv region, the index is $1.6 \%$. Despite of the fact that urban forests represent the small component of total forest covered, they play a key role in maintaining the biosphere stability and are considered to be one of important factors of sustainable development of urban areas.

Nowadays, improvement in forest management and forest ownership distribution is a priority task to implement optimal forest management principles.

Kharkiv city urban forests cover an area of $3,765.8$ ha $(100 \%)$. Of them, 3,364.3 ha $(100 \%)$ is covered with forest vegetation. They include forests of SME 'Kharkivzelenbud' - Kharkiv forest park, the largest park in Ukraine - with the area of 2,092.0 ha (55.6\%), of which $1,696.0$ ha $(50.4 \%)$ is covered with forest vegetation; 512 ha $(13.6 \%)$ of lands of SE 'Zhovtneve FE', of which 506.5 ha (15.1\%) is covered with forest vegetation; and 1161.8 ha $(30.8 \%)$ being in sustained use of SE 'Kharkiv forest research station', of which 1,161.8 ha $(34.5 \%)$ is covered with forest vegetation. 
Table 3. Frequency of common tree species according to forest users, ha/\%

\begin{tabular}{|c|c|c|c|c|}
\hline \multirow[b]{2}{*}{ Species } & \multicolumn{3}{|c|}{ Users } & \multirow[b]{2}{*}{$\begin{array}{l}\text { Total } \\
\text { area }\end{array}$} \\
\hline & 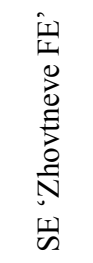 & 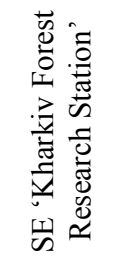 & 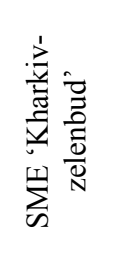 & \\
\hline 1 & 2 & 3 & 4 & 5 \\
\hline \multirow{2}{*}{ Scots pine } & 475.1 & 64 & 118.8 & \multirow{2}{*}{657.9} \\
\hline & 93.9 & 5.5 & 7.0 & \\
\hline \multirow{2}{*}{ Norway spruce } & \multirow{2}{*}{-} & \multirow{2}{*}{-} & 1.2 & \multirow{2}{*}{1.2} \\
\hline & & & 0.1 & \\
\hline \multirow{2}{*}{ English oak } & \multirow{2}{*}{ - } & $1,027.6$ & $1,434.0$ & \multirow{2}{*}{2461.6} \\
\hline & & 88.4 & 84.5 & \\
\hline \multirow{2}{*}{ Red oak } & 1.1 & 2.1 & 1.1 & \multirow{2}{*}{4.3} \\
\hline & 0.2 & 0.2 & 0.1 & \\
\hline \multirow{2}{*}{ Small-leafed lime } & \multirow{2}{*}{-} & 2.3 & 16.5 & \multirow{2}{*}{18.8} \\
\hline & & 0.2 & 1.0 & \\
\hline \multirow{2}{*}{ Field maple } & \multirow{2}{*}{-} & \multirow{2}{*}{-} & 2.9 & \multirow{2}{*}{2.9} \\
\hline & & & 0.2 & \\
\hline \multirow{2}{*}{ Tatarian maple } & \multirow{2}{*}{-} & \multirow{2}{*}{-} & 7.3 & \multirow{2}{*}{7.3} \\
\hline & & & 0.4 & \\
\hline \multirow{2}{*}{ Box-elder } & \multirow[t]{2}{*}{-} & \multirow{2}{*}{-} & 21.6 & \multirow{2}{*}{21.6} \\
\hline & & & 1.3 & \\
\hline \multirow{2}{*}{ Norway maple } & \multirow{2}{*}{-} & 13.7 & 24.8 & \multirow{2}{*}{38.5} \\
\hline & & 1.2 & 1.4 & \\
\hline \multirow{2}{*}{ Silver maple } & \multirow{2}{*}{-} & _- & 1.2 & 1.2 \\
\hline & & & 0.1 & \\
\hline Silyer hirch & 22.9 & 24.2 & 5.5 & 526 \\
\hline 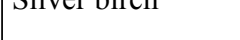 & 4.5 & 2.1 & 0.3 & 52.0 \\
\hline
\end{tabular}

\begin{tabular}{|c|c|c|c|c|}
\hline 1 & 2 & 3 & 4 & 5 \\
\hline \multirow{2}{*}{ Common ash } & \multirow{2}{*}{-} & 4.9 & \multirow{2}{*}{-} & \multirow{2}{*}{4.9} \\
\hline & & 0.4 & & \\
\hline \multirow{2}{*}{ Green ash } & \multirow{2}{*}{-} & \multirow{2}{*}{-} & 9.2 & \multirow{2}{*}{9.2} \\
\hline & & & 0.5 & \\
\hline \multirow{2}{*}{ Aspen } & \multirow{2}{*}{-} & \multirow{2}{*}{-} & 6.0 & \multirow{2}{*}{6.0} \\
\hline & & & 0.4 & \\
\hline \multirow{2}{*}{ Black locust } & \multirow{2}{*}{-} & 6.4 & 16.7 & \multirow{2}{*}{23.1} \\
\hline & & 0.6 & 1.0 & \\
\hline \multirow{2}{*}{ Elm } & \multirow{2}{*}{-} & 3.6 & 2.0 & \multirow{2}{*}{5.6} \\
\hline & & 0.3 & 0.1 & \\
\hline \multirow{2}{*}{ Canadian poplar } & \multirow{2}{*}{-} & \multirow{2}{*}{-} & 11.9 & \multirow{2}{*}{11.9} \\
\hline & & & 0.7 & \\
\hline \multirow{2}{*}{ White poplar } & 0.7 & 2.4 & 6.0 & \multirow{2}{*}{9.1} \\
\hline & 0.1 & 0.2 & 0.4 & \\
\hline \multirow{2}{*}{ Black poplar } & \multirow{2}{*}{-} & 4.8 & 0.1 & \multirow{2}{*}{4.9} \\
\hline & & 0.4 & 0.0 & \\
\hline \multirow{2}{*}{ Lombardy poplar } & \multirow{2}{*}{-} & \multirow{2}{*}{-} & 2.9 & \multirow[b]{2}{*}{2.9} \\
\hline & & & 0.2 & \\
\hline \multirow{2}{*}{$\begin{array}{l}\text { European bird } \\
\text { cherry }\end{array}$} & - & - & 0.5 & 0.5 \\
\hline & & & 0.0 & \\
\hline Common alder & 6.7 & 5.8 & 0.4 & 129 \\
\hline Contintori a fere & 1.3 & 0.5 & 0.0 & 12.9 \\
\hline Rowan & - & - & 2.6 & 26 \\
\hline & & & 0.2 & \\
\hline White willow & - & - & 2.0 & 20 \\
\hline & & - & 0.1 & 2.0 \\
\hline Crack willow & - & - & 0.8 & 0.8 \\
\hline & - & - & 0.0 & \\
\hline Total & 506.5 & $1,161.8$ & $1,696.0$ & $3,364.3$ \\
\hline
\end{tabular}

Table 4. Distribution of average forest inventory indicators by forest users

\begin{tabular}{|c|c|c|c|c|c|}
\hline \multirow{3}{*}{ User } & \multicolumn{5}{|c|}{ Average forest inventory indicators } \\
\hline & \multirow{2}{*}{$\begin{array}{l}\text { Age } \\
\text { (years) }\end{array}$} & \multirow[b]{2}{*}{ Site class } & \multirow{2}{*}{$\begin{array}{l}\text { Stand } \\
\text { density }\end{array}$} & \multicolumn{2}{|c|}{ Standing volume $\left(\mathrm{m}^{3} / \mathrm{ha}\right)$} \\
\hline & & & & $\begin{array}{l}\text { Lands covered with } \\
\text { forest vegetation }\end{array}$ & $\begin{array}{l}\text { Mature and overmature } \\
\text { stands }\end{array}$ \\
\hline SE 'Zhovtneve FE' & 64 & $\mathrm{I}, 9$ & 0.74 & 265 & 202 \\
\hline SE 'Kharkiv Forest Research Station' & 75 & II, 1 & 0.72 & 246 & 232 \\
\hline SME 'Kharkivzelenbud' & 75 & II & 0.66 & 249 & 160 \\
\hline For all users & 73 & II & 0.69 & 253 & 198 \\
\hline
\end{tabular}


The average age ( 73 years) and age groups of forest plantations are significantly different from the optimal age group distribution. This situation requires considerable effort to optimise the structure of forest stands. Optimisation of structure of stands distribution by age groups may significantly enhance recreation, sanitation and health functions of urban forests.

The predominant species are English oak, which occupies $61 \%$ of the area covered with forest vegetation, and Scots pine (27\%). It should also be noted that the state forests have a rather poor range of species as compared to the forests of communal ownership. Expanding the variety of the species will significantly increase water-conservation, protective, sanitary, health, recreational, aesthetic, educational and other functions of urban forests.

\section{Conclusions}

Kharkiv urban forests have been attributed to state and communal ownership. The forestry activities in them are almost identical. The system of inventory and relevant forest management planning should be improved as suggested:

1. Establish map of Kharkiv urban forests for obligatory use during planning city landscaping, park construction and so on.

2. Species range of urban forests should be expanded. However, during forestry activities and landscaping, it is advisable to supplement other species that are distinct in ornamental effect, aesthetic appeal and resistance to anthropogenic factors, including Japanese quince (Chaenomeles japonica (Thunb.) Lindl. ex Spach), Thunberg's barberry (Berberis thunbergii DC.), Amur cork tree (Phellodendron amurense Rupr.), Chinese magnolia vine (Schisandra chinensis (Turcz.) Baill.), large-leaved lime (Tilia platyphyllos Scop.), Siberian larch (Larix sibirica Ledeb.), Mahonia aquifolium (Mahonia aquifolium (Pursh) Nutt.), Weymouth pine (Pinus strobus L.), Crimean pine (P. nigra ssp. Pallasiana (Lamb.) Holmboe), Macedonian pine (Pinus peuce Griseb.), white cedar (Thuja occidentalis L.), Chinese thuja (Platycladus orientalis (L.) Franco), weeping forsythia (Forsythia suspensa (Thunb.) and bird cherry (Prunus padus L.).
3. The age structure of the forests is unbalanced, so relevant measures should be taken to optimise the structure of forest stands in Kharkiv.

\section{References}

Andresen, J.W. 1978. Internationalization of urban forestry. Journal of Arboriculture, 4 (11), 250-257.

Basos, N. 2008. Recent problems of urban forestry in Ukraine. In: Proceedings of the International Youth Science Environmental Forum "ECOBALTICA-2008" (eds.: M.P. Fiodorov, W. Hogland, V.Yu. Rud'), 26-28 June 2008, St.-Petersburg, Russia, 103-105.

Forest Code of Ukraine (in Ukrainian). Available at http://zakon5.rada.gov.ua/laws/show/3852-12 (access on 21 March 2017).

Forests of Ukraine. State Target Program for 2010-2015 years (in Ukrainian). Available at http://zakon2. rada.gov.ua/laws/show/977-2009-\%D0\%BF (access on 21 March 2017).

Instructions of inventory of forest fund of Ukraine (Part 1) (in Ukrainian). 2014. Available at http:// dklg.kmu.gov.ua/forest/control/uk/publish/ article?art_id=119314 (access on 21 March 2017).

Konijnendijk, C.C., Ricard, R.M., Kenney, A., Randrup, T.B. 2006. Defining urban forestry A comparative perspective of North America and Europe. Urban Forestry and Urban Greening, 4 (3-4), 93-103.

Kuchelmeister, G. 1997. Urban trees in arid landscapes: Multipurpose urban forestry for local needs in developing countries. Arid Lands Newsletter. Urban Agriculture in Drylands, 42. Available at https:// cals.arizona.edu/OALS/ALN/aln42/aln42toc.html (access on 21 March 2017).

Kurakin, L.V. 2006. Forests of Kharkiv region (in Ukrainian). Zhurnalistskyi Fond Slobozhanshchiny, Kharkiv, Ukraine.

Pautasso, M. 2009. Geographical genetics and the conservation of forest trees. Perspectives in Plant Ecology, Evolution and Systematics, 11, 157-189.

Rules of maintenance of community landscape in Ukraine (in Ukrainian). Available at http://zakon5.rada.gov.ua/laws/show/z0880-06 (access on 21 March 2017). 
Shackleton, C. 2012. Is there no urban forestry in the developing world? Academic Journals, 7 (40), 3329-3335.

Shvydenko, A.Z., Strochinsky, A.A., Savich, Yu.N., Kashpor, S.N. 1987. Regulatory reference materials for forest inventory of Ukraine and Moldova (in Ukrainian). Urozhay, Kyiv, Ukraine.

Stolberg, F.V. 2000. Urban ecology (in Russian). Libra, Kyiv, Ukraine.
Tasoulas, E., Varras, G., Tsirogiannis, I., Myriounis, Ch. 2013. Development of a GIS application for urban forestry management planning. Procedia Technology, 8, 70-80.

Vedmid, M.M., Meshkova, V.L., Zhezhkun, A.M. 2006. An algorithm for studying areas of low-value young stands in oak forests following the materials of forest surveying. Lisivnytstvo i ahrolisomelioratsiya (Forestry and Forest Melioration), 110, 54-59. 